\title{
THE LAKE MARION REGIONAL WATER SYSTEM: PLANNING A REGIONAL WATER SYSTEM TO SPUR ECONOMIC DEVELOPMENT
}

\author{
Andrew S. Vane, P.E.
}

AUTHORS: Senior Principal Engineer, Hazen and Sawyer, P.C., 4944 Parkway Plaza Boulevard, Suite 375, Charlotte, North Carolina, 28217 REFERENCE: Proceedings of the 2008 South Carolina Water Resources Conference, held October 14-15, 2008, at the Charleston Area Event Center.

\begin{abstract}
In the 1990's, officials from Orangeburg County, South Carolina, approached Santee Cooper, the state-owned electric and water utility, with the prospect of creating a regional water system along the Interstate 95 corridor to encourage economic growth. Unfortunately, this section of interstate highway has even been reportedly identified as the lowest per capita income per mile of interstate. Santee Cooper was successful in developing and putting into operation a 30 million gallon per day (MGD) regional water system for wholesale customers northwest of Charleston, South Carolina. This proposal led to the planning and design of a new regional water system to serve six counties along the I-95 corridor. Hazen and Sawyer (H\&S) of Charlotte, North Carolina (along with co-consultant Engineering Resources Corporation (ERC) of Orangeburg, South Carolina) was selected to assist the parties with the planning and design of this regional water system. Primary funding has been provided through federal government grants and allocations via the Water Resources Development Act (WRDA) and the House Appropriations bills. The project team has been expanded to include the Charleston District of the U.S. Army Corps of Engineers. The ultimate goal of this project is to provide a reliable and high quality drinking water supply to the residents and provide infrastructure to the region at an affordable price. The target wholesale price of water is less than $\$ 1.00$ per thousand gallons. An additional benefit of this project is that many of the small towns will not bear the replacement burden of maintaining and upgrading their existing wells and treatment systems to meet the increasing drinking water standards. Hazen and Sawyer developed a preliminary engineering report for a water system consisting of 65 miles of water transmission mains initially ranging in size from 36-inches in diameter at the water plant to 12 inch diameter mains to ensure the pressures will fill each wholesale users' elevated storage tanks. The preliminary design process consisted of corridor studies for the lines, assessment of environmental and cultural resources impacts, and use of computer hydraulic modeling to plan the system. By tapping into one of the largest drainage
\end{abstract}

basins in the eastern U.S., the project will maximize the sustainability of the water source. The original schedule for this project consisted of design, permitting and construction to be completed within 5 years. As the project progressed, the amount of funding available began to vary requiring the project to be divided into various transmission main reaches. Further lack of federal funding due to Hurricane Katrina delayed the project for 1-1/2 years. The project has since restarted with construction of the water treatment plant and the first transmission main completed.

\section{NEED FOR PROJECT}

Today, the State of South Carolina lags well behind the national average in median value of housing units, median household income and retail sales per capita while it is ahead of the national averages in percentage of minorities, percentage of persons below the poverty level and population growth percentage (US Census, 2000). This means that the state is growing in population, while economic and social growth continues to lag behind. In fact, some communities within the project region are reported to have a per capita income from $40 \%$ to $47 \%$ of the national average (US Census, 2006). In recent years, some growth in the six county region has come from rapid development outside the City of Charleston and in some retirement communities. However, the pace of this development has been slow in recent years. Lakefront community real estate brokers have followed the trend to increase property values, while income to local inhabitants has seen only slight growth in the past few years. This has resulted in an increasing affordability gap of housing with low turnover of existing homes. For example, while South Carolina's per capita income has increased from $\$ 24,424$ to $\$ 29,515$, an increase of $20.8 \%$ from 2000 through 2006 (US Dept. of Commerce, 2006), a sampling of property values (Orangeburg County GIS, 2008) for the Town of Santee, the center of the project's region, indicated an increase of $100 \%$ to $360 \%$ over the same period. This data indicates that property values are 


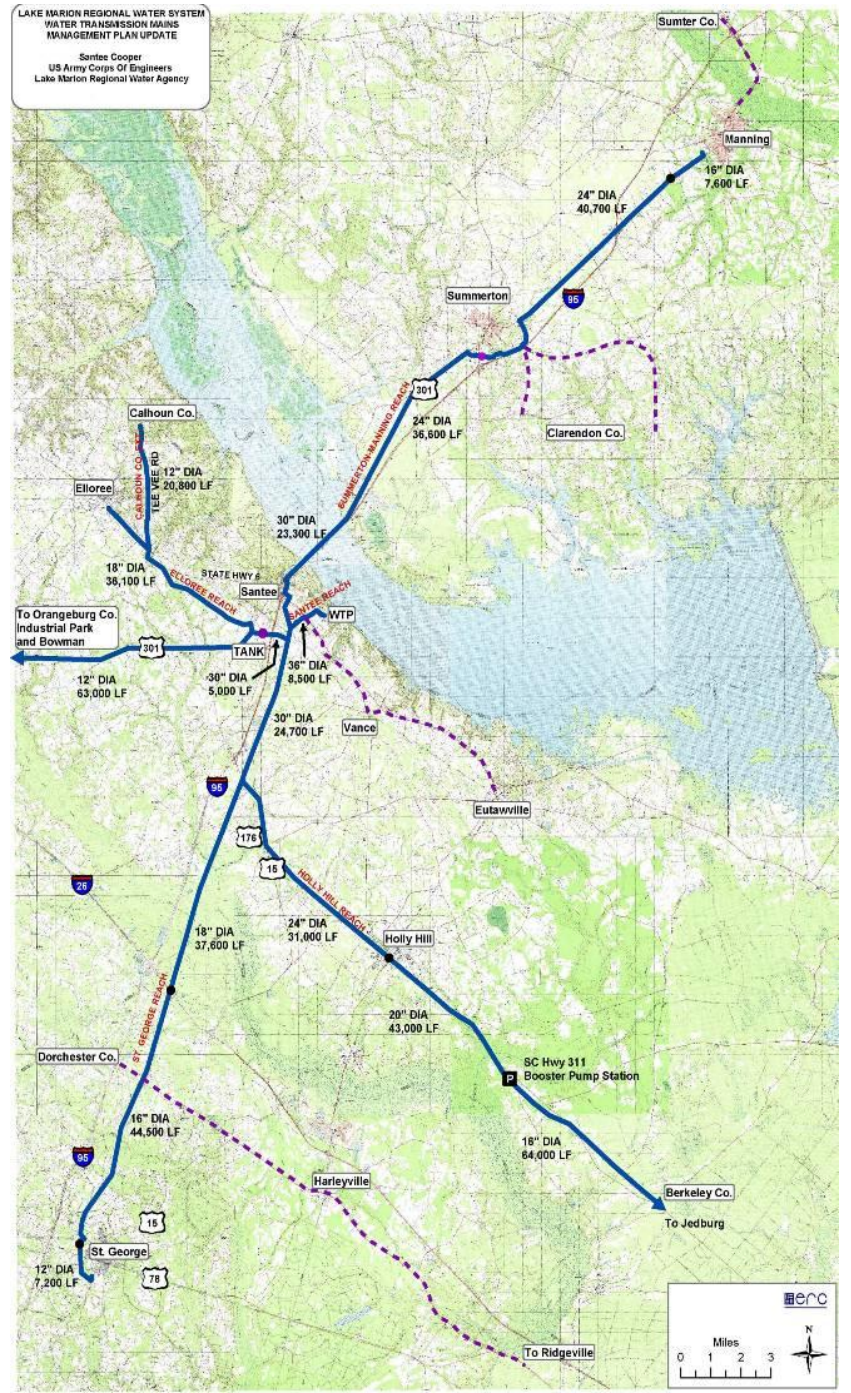

Current envisioned project.

climbing at an alarming rate while per capita income is not keeping pace.

In addition, recent droughts have resulted in an increased concern for a reliable and sustainable raw water source. Most small towns in the proposed service area currently use public supply groundwater wells as a source which provides minimal treatment. This results in a finished drinking water often with poor taste from a source with unknown reliability. The proposed project will serve a region of six (6) counties along the Interstate 95 and Interstate 26 corridors as indicated on the map above.

While not all areas of each county will be served by this water system, the primary corridors along the interstates and their current developments will be provided with adequate transmission of finished water on a wholesale basis.

\section{SANTEE COOPER'S EXISTING REGIONAL WATER SYSTEM}

Santee Cooper, South Carolina's state-owned public water and electric utility, has been quite successful in developing a regional water system for four (4) wholesale users at the southern end of Lake Moultrie. Under this current system, Santee Cooper owns, operates and maintains the water treatment plant and water transmission mains, while the Berkeley County Water \& Sanitation Authority, City of Goose Creek, Moncks Corner Commissioners of Public Works and Summerville Public Works Commission own the water treatment plant's capacity. Wholesale users bought into the system by offering initial user capital fees which are designated towards capital improvements and associated debt reduction from improvements. Wholesale user fees have historically been less than $\$ 1.00$ per thousand gallons of water with varying user rates based on the quantity of capital costs paid at the onset of joining the regional system. This 36 MGD regional water system has provided reliable and high quality finished drinking water to its users continuously since 1995 .

\section{FORMATION OF THE AGENCY}

In order to stimulate growth and create infrastructure for industries and commercial enterprises, Orangeburg County in 1990 approached Santee Cooper with the prospect of creating a regional water system along the I95 corridor. After meetings and careful consideration, the Lake Marion Regional Agency (LMRWA) was established. It consisted of six (6) counties with one commissioner from each county serving as an agency representative. The agency was originally comprised of the counties of Calhoun, Clarendon, Colleton, Dorchester, Orangeburg, and Sumter. Colleton County eventually resigned due to the perceived impractability of the distance from the proposed water treatment plant site on Lake Marion to the county's population center. Berkeley County was later added as a member based on a need for additional water due to rapid population growth. As the project took shape, the additional municipalities of Santee, Holly Hill, Elloree, St. George, Sumter, Summerton, Manning, and Turbeville were added to the agency bringing its total membership to eleven. In 2006, as the water supply contracts were being developed, capacity commitments were requested of each member whereby some members opted out of the agency in favor of self-providing water or purchasing directly from a county member. 


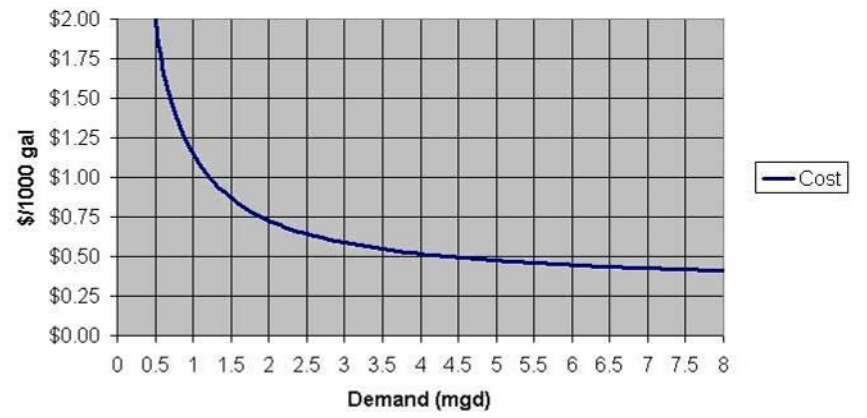

Cost of water.

Due to the economic conditions of the region, producing water for this area brings with it the goal of not significantly increasing the water costs to the existing residents. It is by using federal grant funding with local matching funding coming primarily from state bond bills that wholesale rates could be kept to a minimum. Further contributors to limiting the cost of water are operating the water treatment plant remotely, purchasing chemicals in bulk, and constructing the plant so it is easily expandable to 12 MGD with minimal improvements. The above figure shows how the cost of water is related to the quantity of water produced. Minimum fixed costs cause the total cost to level at slightly less than $\$ 0.50$ per thousand gallons regardless of the quantity sold at some point.

In order to provide water as economically as possible, it was determined early during the planning phase that little or no debt could be serviced. Since a multi-million dollar project of this scale would incur massive long term debt using conventional funding methods (i.e., bonds and low-interest loans) it was determined that grant funding was essential for this project. Perhaps the LMRWA's greatest supporter, US House Representative James Clyburn, championed an initial \$20 million in 2004 for construction to make the project a reality. The method of funding used by Congressman Clyburn has been historically through annual House appropriations bills and WRDA.

\section{PRELIMINARY DESIGN}

The original project, as envisioned in 2001, consisted of a water treatment plant, elevated storage tank, and 65 miles of water transmission mains measuring 12-inches in diameter through 36-inches in diameter with a total estimated capital cost of $\$ 65$ million. The project was proposed to be bid and constructed over a five (5) year period. Hydraulic modeling of the entire system was performed using the University of Kentucky's KYPIPE and eventually US Environmental Protection Agency's

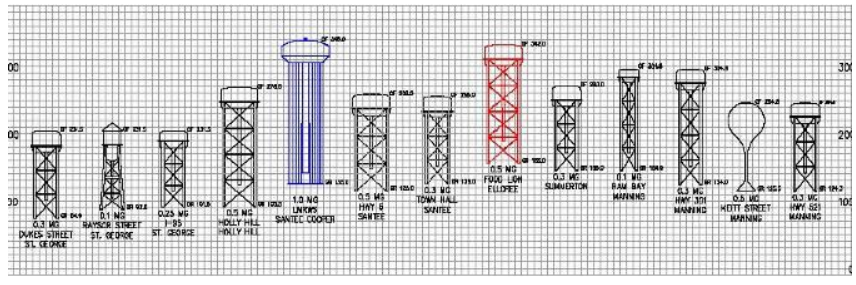

Elevated storage tanks

EPANET hydraulic modeling software. A preliminary engineering report for the water transmission mains was prepared by the design consultants, H\&S and ERC, and presented to the Agency in 2002.

The water transmission main system was originally designed so that no booster pumping facilities would be utilized since their operation and maintenance would impose additional costs directly related to the overall wholesale cost of water. As part of this design process, the anticipated demands were determined based on each user taking $100 \%$ of their water from the LMRWA. The regional water system was designed to meet each wholesale user's projected 2025 maximum day demands while maintaining the ability to fill their elevated storage tanks.

The hydraulic modeling determined that the 1.0 MG elevated storage tank would need to be approximately 225 feet high with an Hydraulic Grade Line (HGL) of 348 feet in order to fill each wholesale user's tanks under maximum day demand conditions. The above figure depicts the existing elevated storage tanks in the system in comparison with the new LMRWA elevated storage tank. The Town of Elloree's Food Lion Tank, the tank with the highest overflow elevation, determined the overflow elevation of 348.0 feet of the new 1.0 MG elevated tank.

The later addition of Berkeley County to the Agency with its commitment of 2.5 MGD will ultimately require a booster pumping station in the southeast region.

\section{ROADBLOCKS ALONG THE WAY}

In 2001, much of the southeast experienced a significant drought. While design was underway for the various pipeline reaches, the lake levels continued to drop. The Santee River, which flows into Lake Marion, experienced its lowest reported flow rates since 1992 (USGS, 2008). While this made for easy access to many swampy areas along the pipeline routes during evaluation and assessment, it reaffirmed the need for a reliable raw water source in the region.

In 2003, bidding and award of a construction contract for the proposed Water Treatment Plant on the south side of Lake Marion was initiated by the contract 
administrators without enough available funding in place. The contract administrators anticipated that additional funding would be forthcoming. As expected, Congressman Clyburn attempted to push through Congress a House Appropriations Bill with additional funding to prevent a shutdown.

It was shortly thereafter that Hurricane Katrina struck the Gulf Coast. Congress put an immediate hold on most spending legislation in an effort to divert as much money as possible to those in need. This meant that monies intended for the project on bills moving through Congress were buried to address the catastrophe. As the year approached to a close, it was evident that monies would not be forthcoming and construction of the water treatment plant was halted. This shutdown lasted approximately 18 months.

As time progressed, additional funding for the project was sought both locally and in Washington DC. A South Carolina State Bond Bill was introduced in the State Legislature which was vetoed by the Governor. However, the legislative body obtained enough votes to override the veto and the bill passed, resulting in another $\$ 8$ million in local matching money for the project. In Washington DC, \$20 million for the project was proposed in the annual WRDA bill. After passing both houses, the President vetoed the bill on the last day it would have passed without his action. Despite recent failures to override the President's veto on other bills, enough congressional support was obtained for the WRDA Bill and Congress voted to override the veto. Despite political obstructions and tight spending constraints, the larger legislative bodies in the State and Federal governments raised enough support to ensure the project could be funded and restarted.

In the last two years, extreme droughts in the southeast have furthered the need for this project. While groundwater aquifer levels have not run dry, there is an increased concern among local residents over the sustainability of the watershed based on extremely low lake levels. Santee Cooper has provided for a contingency plan to obtain water from Lakes Marion and Moultrie for their water treatment plants, should the levels drop further to critical points.

\section{MANAGEMENT PLAN}

In addition to struggles in funding efforts, local politics at one point in time placed the project at a potential risk for derailment. In an effort to get the project back on track, the LMRWA established a Technical Advisory Group (TAG) consisting of representatives (municipal and county administrators for each member) with the ability to utilize manpower and equipment. One mission of the TAG was to develop an independent Management
Plan for the LMRWA to identify problems, discuss practical solutions and make recommendations for implementation. With input from the TAG, H\&S, and ERC, we developed a unique document which brought to light many issues impeding progress with proposed solutions. The Management Plan became a business plan for the LMRWA by which they could identify work tasks and vote effectively to move the project forward. The Management Plan also re-identified the project scope since the agency membership had gone through some changes since the original Preliminary Engineering Report was developed. The current project consists of approximately 92 miles of transmission mains 12-inches in diameter through 36-inches in diameter and a booster pumping station at the Orangeburg/Berkeley County border.

\section{BACK ON TRACK - THE FIRST PIPELINE REACH}

Recent additions to the funding resulted in enough to construct the first transmission main to connect the new water treatment plant to the Town of Santee. The 3,400 linear feet of 36-inch diameter transmission main was installed as a change order to the current contract from the newly constructed water treatment plant, along Graveyard Rock and Laredo Roads, to the Town of Santee's existing distribution pipeline at US Highway 6. The pipe was installed in approximately 3 months and was successfully tested to $225 \mathrm{psi}$, which is 1.5 times the anticipated 150 psi working pressure. The Ductile Iron Pipe (DIP) was manufactured by ACIPCO in Birmingham, Alabama and equipped with combination air release valves, main line butterfly valves, and a pressure reducing valve at the Town of Santee tie-in point. The following photo depicts one of the DIP joints being installed along Laredo Road.

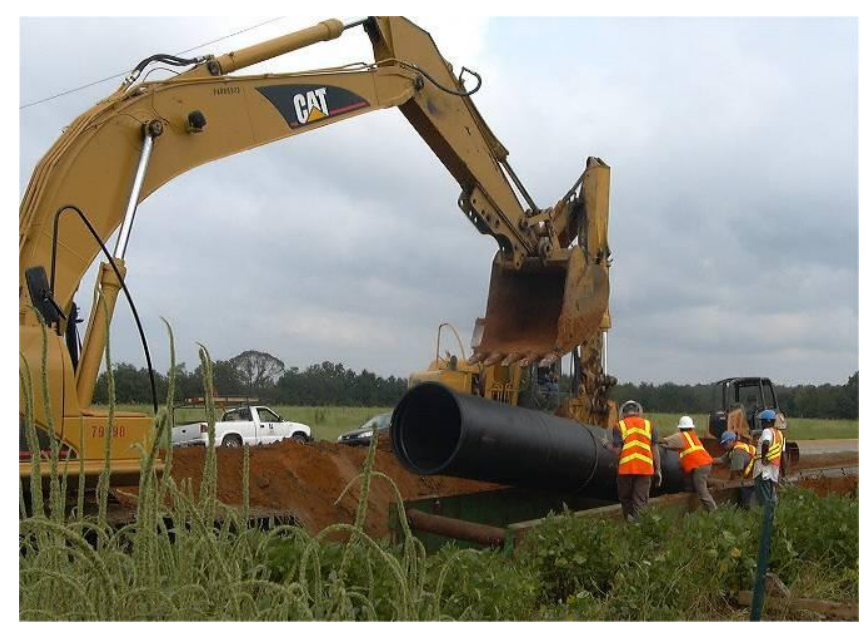

Pipeline installation. 


\section{VISION FOR THE FUTURE}

With the water treatment plant expected to be placed on line in 2008 and the first transmission main reach completed and ready for water, the project is now a reality and the people of the Town of Santee will soon be enjoying a better tasting, higher quality and more reliable drinking water than ever before. Future phases of the project to tie into the 1.0 MG elevated storage tank are nearing design completion, and corridor studies have been completed for the pipeline reach to Berkeley County. TAG members and the design engineers are also studying and investigating additional reaches to other wholesale users and developing areas throughout the region. In addition, a private development company recently purchased 1500 acres of land southeast of the Town of Santee with the intention of building an inland port with rail and semi-truck facilities. This new development is estimated to create approximately 5,000 jobs in the next several years - one of the many benefits of having a reliable water infrastructure in place with a sustainable water source for the future.

\section{ACKNOWLEDGEMENTS}

Congressman James Clyburn (D) of South Carolina

Lake Marion Regional Water Agency (Johnnie Wright, Chairman)

Santee Cooper, South Carolina's Electric and Water Utility (Darla Barnette, P.E., Water System Manager)

U.S. Army Corps of Engineers Charleston District

Engineering Resources Corporation (ERC), Orangeburg, South Carolina (George Aull, PhD, P.E., President)

\section{LITERATURE CITED}

Orangeburg County Geographical Information Systems, 2008, http://www.orangeburgcounty.org/GIS/, Sampling of 4 random properties in Santee, SC based upon Year 2000 value vs. Year 2006 value.

US Census Bureau, 2000, Quick Facts, http://quickfacts.census.gov. South_Carolina_locations_by_per_capita_income.

US Census Bureau, median household income by state 2006.

US Department of Commerce, 2006, Bureau of Economic Analysis.

(http://www.bea.gov/regional/reis/).

US Geological Survey, 2008, USGS Surface-Water

Annual Statistics for the Nation, USGS 02171500

SANTEE, waterdata.usgs.gov, Average Mean statistics

Downstream of Santee Dam at coordinates

North $33^{\circ} 27^{\prime} 15^{\prime \prime}$ West $80^{\circ} 08^{\prime} 30^{\prime \prime}$. 